\title{
MANPOWER PLANNING IN THE APPLICATION OF TEAT DIPPING TO CONTROL SUB CLINICAL MASTITIS IN THE SMALL DAIRY FARMS
}

\author{
Raden Isma Anggraini*)1, Etih Sudarnika ${ }^{* *}$, Herwin Pisestyani**), Ardilasunu Wicaksono ${ }^{* * *}$, \\ and Mirnawati Sudarwanto**) \\ *) School of Business, IPB University \\ Jl. Raya Padjajaran, Bogor 16151, Indonesia \\ ${ }^{* *}$ Department of Animal Disease and Veterinary Public Health, Faculty of Veterinary Medicine, IPB University \\ Jl Dramaga, Kampus IPB Dramaga, Bogor 16680, Indonesia
}

\begin{abstract}
The application of teat dipping to control subclinical mastitis especially in small dairy farms is important; however, the application needs additional activity that has an impact on labor usage. This paper aimed to describe the labor usage to apply teat dipping for subclinical mastitis control in the small dairy farms. The convenience sampling techniques applied to select 34 farmers in Bogor as the respondents. Workload analysis and labor productivity were used in examining the application of dot dipping in various small dairy farms in Bogor City to control subclinical mastitis. This study was based on two types of experiments in small dairy farms in Bogor, West Java, namely teat dipping and without teat dipping. The findings show that the application of teat dipping had an impact on three things, namely an increase in labor usage and its workload, an increase in labor productivity and a decrease in the number of subclinical mastitis prevalence. This study concluded that labor was an important factor to control subclinical mastitis in small dairy farms. An increase in labor productivity had an impact on reducing the costs of mastitis treatment and finally increase farmer's income.
\end{abstract}

Keywords: mastitis, labor, small dairy farms, teat dipping, workload analysis

\begin{abstract}
Abstrak: Aplikasi teat dipping untuk mengendalikan penyakit mastitis subklinis terutama di peternakan sapi perah memiliki peranan penting, namun, aplikasi tersebut membutuhkan aktivitas tambahan yang berdampak pada penggunaan tenaga kerja. Studi ini bertujuan untukmenggambarkan penggunaan tenaga kerja dalam menerapkan teat dipping untuk kontrol mastitis subklinis di peternakan sapi perah kecil. Pemilihan responden menggunakan teknik convenience sampling kepada 34 peternak sapi di Bogor. Data dianalisis menggunakan metode deskriptif. Analisis beban kerja (ABK) dan produktivitas tenaga kerja digunakan untuk menguji penerapan teat dipping di berbagai peternakan sapi perah kecil di Kota Bogor guna mengendalikan penyakit mastitis subklinis. Penelitian ini didasarkan pada dua jenis percobaan di peternakan sapi perah kecil di Bogor, Jawa Barat yaitu teat dipping dan tanpa teat dipping. Hasil penelitian menunjukkan bahwa penerapan teat dipping berdampak pada tiga hal, yaitu peningkatan penggunaan tenaga kerja dan beban kerjanya, peningkatan produktivitas tenaga kerja dan penurunan jumlah prevalensi mastitis subklinis. Studi ini menyimpulkan bahwa tenaga kerja merupakan faktor penting untuk mengendalikan mastitis subklinis di peternakan sapi perah kecil. Peningkatan produktivitas tenaga kerja berdampak pada berkurangnya biaya pengobatan sapi akibat penyakit mastitis yang pada akhirnya meningkatkan pendapatan peternak.
\end{abstract}

Kata kunci: analisis beban kerja, mastitis, teat dipping, peternakan sapi perah kecil, tenaga kerja

\footnotetext{
${ }^{1}$ Corresponding author:

Email: isma.anggraini@apps.ipb.ac.id
} 


\section{INTRODUCTION}

One of the important problems in livestock management is disease control (Rakhmat and Indrawan, 2019). In the management of dairy farming businesses in several developing countries, mastitis is a major problem because it can cause a decrease in milk production in large quantities (Nurhayati and Martindah, 2015). Mastitis is well known as an endemic disease that has a significant economic loss in the dairy industry, especially in small farms (Gussmann et al. 2019). Mastitis may influence cows to yield less milk and reduced quality or even inconsumable milk (Huijips et al. 2008). One of the factors that can inhibit increased milk production in a small dairy farm is mastitis which is defined as inflammation of the internal tissue of the udder. The more severe the incidence of mastitis in cattle, the greater the decrease in the amount of milk production (Pujiati and Indrianto, 2009).

Mastitis can be subclinical and clinical. Mastitis takes place subclinically if clinical symptoms of inflammation cannot be found at the time of the udder examination. Clinical mastitis is characterized by swelling, heat when touched and pain in the infected udder. The incidence of subclinical mastitis can reach 50 times compared with clinical mastitis. Cases of subclinical mastitis in the field such as the phenomenon of the iceberg, the population of cattle suffering from subclinical mastitis can reach 20-40 times that of the livestock population suffering from clinical mastitis (Hameed et al. 2006). The prevalence of subclinical mastitis in Indonesia is still high at $85 \%$ (Rahayu, 2007). Teat dipping is one method that farmers use to minimize mastitis. The majority of dairy farms in Indonesia are small dairy farms so that they still unable to achieve large profits due to constraints in several ways. These obstacles cause low production of milk which can lead farmers to the losses (Sanotharan et al. 2016). One of the obstacles is the occurrence of subclinical mastitis which significantly reduced milk production (Pisestyani et al. 2017).

One way to prevent and overcome the incidence of subclinical mastitis in small dairy farms is by using teat dipping after post milking (Putri et al. 2015). Teat dipping has been widely carried out and has been widely accepted as one of the treatments to reduce mammary gland infections. Teat dipping is applied using antiseptics fluids that can eliminate microorganisms and protect the nipples from infection so that udder health can be maintained and the incidence of subclinical mastitis can be prevented (Magnusson et al. 2006, Castro et al. 2012).

To control the prevalence of subclinical mastitis, the application of teat dipping mentioned experts can reduce the likelihood of subclinical mastitis and prevent the spread to healthy cows. However, the application of teat dipping to control subclinical mastitis will require additional activities that have an impact on increasing the number of workers. This additional workforce will discourage farmers from dipping to control subclinical mastitis especially when there is no significant benefit. Therefore, the addition of manpower must be calculated and described to ensure and motivate farmers to do the teat dipping.

Labor calculations analysis in teat dipping on a small dairy farm in Bogor City has never been done before. In many small farmers in Bogor city, the incidence of subclinical mastitis could reach more than 80 percent higher than clinical mastitis (Etih et al. 2019). Many small farmers in Bogor needs the application of teatdipping to control subclinical mastitis. Therefore, the purpose of this study is to describe the needs of labor in the treatment of teat dipping to prevent subclinical mastitis in small dairy farms and its impact on labor costs that will arise. An increase in the labor force will increase the labor cost. It is necessary to calculate the right amount of labor so that the cost of labor requires becomes more efficient.

\section{METHODS}

Workload analysis (WLA) and economic value based on productivity of labor were used to evaluate the application of teat dipping in various small dairy farms in Bogor City. WLA is an action that aims to find out the amount of time needed by employees to complete a job Pranoto dan Retnowati (2015). By doing WLA, it is expected to know the number of workers needed in completing a job in an organization. WLA is a method for calculating workload index which it calculates the amount of labor needed to complete the workload.

The unit used to calculate the workforce or person needs to complete a job is often called a full-time equivalent (FTE). FTE is assumed to be a measure of the time required to carry out activities in a comprehensive or full manner. One FTE is equivalent to one person 
who works full time in the current calendar year. The implication of FTE value is divided into three types namely; overload, normal and underload. Based on WLA guidelines issued by the Personal Agency Countries in 2010, the total index value FTE there are: i) above 1,28 is considered overload, ii) between values 1 until 1,28 is considered normal, iii) whereas if the FTE index value is between 0 up to 0,99 is considered under-loaded (the workload is lacking).

Productivity analysis aims to achieve efficiency by comparing the output and input of a cow's milk production. Cow's milk production productivity is defined as the amount of milk produced divided by the number of milking milk at each cattle farm. Prevalence is defined as all populations suffering from disease from populations at risk of developing the disease within a certain time period. Somatic cell count (SCC) is one of the udder health parameters and is associated with subclinical mastitis (Schalm, 1971).

This study collected primary data and secondary data. Primary data based on experimental data collected in three small dairy farms in Bogor in 2019 namely Edufarm, H. Acep Farm and A Taufik Farm with two things namely control and treatment. The experiment was carried out and measured on four nipples of 34 cattle on the farm (Table 1). The three small dairy farms located in the Bogor livestock business area, called KUNAK (Kawasan Usaha Peternakan). This study also collected secondary data from relevant literature.

The experiment and FTE, productivity and model were developed as follows: 1) The experiment was differentiated between two types of cows: without treatment (control) and treatment; 2) There were three things that are counted consecutive $d$ analyzed in this study, namely FTE, productivity and prevalence; 3) The FTE was measured weekly for 13 consecutive weeks; 4) The milk production was measured weekly for 13 consecutive weeks; 5)The effect of control and treatment was measured and compared by bulk tank somatic cell count for 13 consecutive weeks; 6) FTE calculations were carried out in the following stages: FTE calculations were performed on conditions that do not receive the treatment of teat dipping (control) and condition that is treated with the teat dipping (treatment); Calculated the total number of hours worked in producing the amount of milk; Divided the results by 13 weeks (the length of the experiment); Divided by the number of cows each breeder has; Assumed real work hours for milking a cow for 20 (twenty) hours; Reduced the results of item c by 20; Calculated the FTE with the formula: total work hours/number of real work hours. 7) Productivity was calculated using the formula: (amount of cow's milk produced / real working hours) $x 100 \%$; 8 ) The diagnosis of mastitis subclinical was done by counting the number of somatic cells or somatic cell count (SCC). If the SCC is more than or equal to 400,000 cells / $\mathrm{mL}\left(0.4 \times 10^{6}\right)$, it is tested positive for subclinical mastitis.

\section{RESULTS}

This study found that the application of teat dipping had an impact on increasing labor requirements or FTE (Table 2). On average, before the teat-dipping treatment only one worker was needed, whereas, after the teatdipping treatment, 2 workers were needed. Table 1 describes that, without application of teat dipping, the FTE of three small dairy farms were normal, on the other hand, the application of teat dipping impact the FTE were overload. The result showed that the application of teat dipping increased labor usage and its workload.

The study also found that the application of teat dipping by farmers had increased the productivity of workers in producing milk (Table 3 and Table 4). On average, the application of teat dipping will increase labor productivity by 23.41 percent.

This study found that the application of teat dipping reduced the prevalence of nipple 1 and nipple 4 by 56.89 percent and 42.41 percent respectively. However, the experiments on nipple 2 and nipple 3 showed that the application of teat-dipping had no effect on reducing the prevalence and instead tends to increase prevalence (Table 5 and Table 6).

Table 1. Descriptive information on the farm experiment

\begin{tabular}{lccc}
\hline Information & Edufarm & $\begin{array}{c}\text { H. Acef } \\
\text { Farm }\end{array}$ & $\begin{array}{c}\text { A. Taufiq } \\
\text { Farm }\end{array}$ \\
\hline Control & & & \\
Cows & 15 & 3 & \\
Observation & 558 & 98 & \\
Treatment & & & \\
Cows & & 14 & 2 \\
Observation & & 734 & 104 \\
\hline
\end{tabular}


Table 2. FTE comparison between control and treatment

\begin{tabular}{|c|c|c|c|c|}
\hline \multirow{3}{*}{ Farm } & \multicolumn{4}{|c|}{ FTE (person) } \\
\hline & \multicolumn{4}{|c|}{ Control } \\
\hline & 1 & 2 & 3 & 4 \\
\hline Edufarm & 1.05 & 1.04 & 1.05 & 1.06 \\
\hline H.Acep Farm & 1.06 & 1.06 & 1.07 & 1.07 \\
\hline \multirow[t]{3}{*}{ A.Taufik Farm } & - & - & - & - \\
\hline & \multicolumn{4}{|c|}{ Treatment } \\
\hline & 1 & 2 & 3 & 4 \\
\hline Edufarm & - & - & - & - \\
\hline H.Acep Farm & 1.39 & 1.50 & 1.48 & 1.32 \\
\hline A.Taufik Farm & 1.43 & 1.51 & 1.51 & 1.49 \\
\hline
\end{tabular}

Teat number1 referred to the right-front, teat number 2 referred to the right-back, teat number 3 referred to left-back, and teat number 4 referred to left-front.

Table 3. Productivity comparison between control and treatment

\begin{tabular}{lcccc}
\hline \multirow{2}{*}{ Farm } & \multicolumn{4}{c}{ Productivity (litre/person) } \\
\cline { 2 - 5 } & 1 & 2 & 3 & 4 \\
\hline Edufarm & 38,484 & 48,112 & 37,984 & 31,340 \\
H.Acep Farm & 33,680 & 34,960 & 31,760 & 30,060 \\
A.Taufik Farm & - & - & - & - \\
\hline \multicolumn{5}{c}{ Productivity (litre/person) } \\
\hline \multicolumn{5}{c}{ Treatment } \\
\hline Edufarm & 1 & 2 & 3 & 4 \\
H.Acep Farm & - & - & - & - \\
A.Taufik Farm & 38,066 & 46,300 & 44,920 & 32,089 \\
\hline
\end{tabular}

Table 4. The productivity percentage comparison of $\mathrm{H}$ Acep Farm

\begin{tabular}{|c|c|c|c|}
\hline $\begin{array}{l}\text { Productivity } \\
\text { (litre/person) }\end{array}$ & Control & Treatment & $\%$ \\
\hline 1 & 33,680 & 38,066 & 13.02 \\
\hline 2 & 34,960 & 46,300 & 32.44 \\
\hline 3 & 31,760 & 44,920 & 41.43 \\
\hline 4 & 30,060 & 32,089 & 6.75 \\
\hline \multicolumn{3}{|c|}{ Average Percentage of Changes } & 23.41 \\
\hline
\end{tabular}

The findings show that the application of teat dipping had an impact on three things, namely an increase in labor requirements or FTE, an increase in labor productivity and a decrease in the number of subclinical mastitis prevalence.

The teat-dipping application required additional labor to provide antibiotics for cows. Based on the calculation of workload analysis, teat-dipping applications by breeders had an impact on increasing labor requirements or FTE (Table 1). On average, before doing the teat dipping application only one cage child was needed, but after receiving the dot dipping treatment, it took 2 workers. This means that teat-dipping treatment requires an additional workforce of 100 percent compared with no treatment.

The applications of teat dipping applications can increase labor productivity on farms. Based on thirteen weeks of experiments on a several number of cow in three farms, the average nipple dyeing treatment on all four nipples increased labor productivity by 23.41 percent. It indicates that there was an increase in milk production in cattle that were experiencing teat dipping treatment. Milk production obtained was the result of milking in the morning. The average milk production shows that there was an increase in the amount of milk production in dairy cows given nipple treatment compared to dairy cows used as control or without treatment for thirteen weeks. The milk production can be increased by dipping the nipples using antiseptics after milking was complete. This is also a good management strategy to reduce the rate of subclinical mastitis infection in dairy cows (Rahayu, 2007). Nipple dip is a treatment of dipping the nipple in an antiseptic solution for a certain amount of time after milking to prevent the entry of pathogenic bacteria into the udder and prevent mastitis (Pujiati and Indrianto, 2009). Therefore, an increase in labor productivity has an impact to reducing the costs of mastitis treatment.

Application of teat dipping by farmers can reduce the prevalence of subclinical mastitis even though it has not been able to eliminate 100 percent. This study shows that the teat dipping treatment had not been effective in reducing prevalence. Nurhayati and Martindah (2015) states that antibiotic treatment is an alternative policy in controlling subclinical mastitis because the success rate can reach 90 percent. 
Table 5. The prevalence comparison between control and treatment

\begin{tabular}{lcccc}
\hline \multirow{2}{*}{ Farm } & \multicolumn{4}{c}{ Prevalence (\%) } \\
\cline { 2 - 5 } & 1 & 2 & 3 & 4 \\
\hline Edufarm & 2.51 & 1.23 & 1.42 & 1.00 \\
H.Acep Farm & 2.62 & 0.87 & 1.52 & 3.19 \\
A.Taufik Farm & - & - & - & - \\
\hline \multicolumn{5}{c}{ Prevalence (\%) } \\
\hline \multicolumn{5}{c}{ Treatment } \\
\hline Edufarm & 1 & 2 & 3 & 4 \\
H.Acep Farm & - & - & - & - \\
A.Taufik Farm & 1.67 & 1.33 & 1.63 & 2.24 \\
\hline & 2.07 & 1.31 & 0.67 & 0.68 \\
\hline
\end{tabular}

Table 6. The prevalence percentage comparison of $\mathrm{H}$ Acep Farm

\begin{tabular}{cccc}
\hline Prevalence & Control & Treatment & $\%$ \\
\hline 1 & 2.62 & 1.67 & 56.89 \\
2 & 0.87 & 1.33 & $(34.59)$ \\
3 & 1.52 & 1.63 & $(6.74)$ \\
4 & 3.19 & 2.24 & 42.41 \\
\hline
\end{tabular}

Our hypothesis, most likely, there was a technical error by farmers in applying teat dipping. The farmers can cooperate with relevant agencies to organize counseling activities and conduct proper teat dipping training. With this counseling and training activity, aside from being able to further raise the awareness of breeders and their workforce to routinely carry out teat dipping actions, they can also improve the technical expertise of teat dipping treatment for livestock so that udder health can be maintained. Thus, to reduce the prevalence of subclinical mastitis, farmers in the small dairy farmers need to be trained on good milking practices, including regular use of teat dips, application of teat dipping and subclinical mastitis screening. These activities will improve their sales and their financial status (Mpatswenumugabo et al. 2017)

Farmers are also encouraged to educate the importance of implementing good livestock management, including the importance of providing quality feed and drinking water, paying attention to the cleanliness of the stable, and the separation of sick and healthy animals. Education and training activities for farmers are expected to improve the skills of farmers. Good skills will improve the quality of handling of livestock, including the application of teat dipping in cattle. This is in line with the suggestion stated in a study which states that farmers are advised to conduct livestock management properly, by putting dipping routinely after milking using antiseptics (Lubis, 2016). The farmers also have to keep milking hygiene and keep environmental sanitation on dairy farms (Abrahmsen et al. 2014; Beyene and Tolosa, 2017; Rakhmat and Indrawan, 2019).

\section{Managerial Implications}

Managerial policies need to be developed which are expected to provide support to the farmers. The implication of the results of this study is the need for government action to support in continuing teat dipping training. Government support also needed to educate the farmers about the importance of good livestock management.

\section{CONCLUSIONS AND RECOMMENDATIONS}

\section{Conclusions}

The findings show that the application of teat dipping has an impact on three things, namely an increase in labor usage and its workload, an increase in labor productivity and a decrease in the number of subclinical mastitis prevalence. This study concludes that labor was an important factor to control subclinical mastitis in small dairy farms. An increase in labor productivity has an impact on reducing the costs of mastitis treatment. With the treatment of teat dipping in cows, it has an impact on increasing the need for labor or FTE. The addition of the workforce is effectively capable of increasing cow milk production, but it has not been effective in reducing the prevalence of subclinical mastitis.

Therefore, the workforce owned by farmers should be able to improve their knowledge, behavior and abilities related to the application of teat dipping and livestock management widely through extension activities and training organized by relevant institutions. These activities will improve their sales and their financial status, and the application of teat dipping can increase the economic benefit for dairy farms (Wicaksono et al. 2017). 


\section{Recommendations}

Manpower planning in the application of teat dipping is the important element to increase labor productivity and to reduce the prevalence of subclinical mastitis. Government support is needed to educate the farmers related to the importance of teat dipping and good livestock management, not only through socialization but also in the form training to the farmers. The limitation of this study just only calculate the productivity based on labor, not calculate productivity base on a cow. Therefore, the further research is needed to analyze this study to calculate productivity based on cow.

\section{ACKNOWLEDGEMENTS}

We thank The Ministry of Research, Technology and Higher Education for funding this activities. We also thank all the farners and all the team member.

\section{REFERENCES}

Abrahamsen M, Persson Y, Kanyima BM, Bage R. 2014. Prevalence of subclinical mastitis in dairy farms in urban and peri-urban areas of Kampala, Uganda. Tropical Animal Health and Production 46:99-105. https://doi.org/10.1007/s11250-0130455-7.

Beyene B, Tolosa T. 2017. Epidemiology and financial impact of bovine mastitis in an animal production and research center and smallholder dairy farms in Horo Guduru Wollega Zone, Western Ethiopia. Journal Dairy Veterinary Animal 5:1-9. https:// doi.org/10.15406/jdvar.2017.05.00152.

Castro SI, Berthiaume R, Robichaud A, Lacasse P. 2012. Effects of iodine intake and teat dipping practices on milk iodine concentrations in dairy cows. Journal Dairy Science 95:213-220. https://doi.org/10.3168/jds.2011-4679.

Gussmann M, Steeneveld W, Kirkeby C, Hogeveen H, Farre M, Halasa T. 2019. Economic and epidemiological impact of different intervention strategies for subclinical and clinical mastitis. Preventive Veterinary Medicine 166:78-85. https://doi. org/10.1016/j.prevetmed.2019.03.001.

Hameed KGA, Sender G, Kossakowska AK. 2007. Public health hazard to mastitis in dairy cows. Animal Science Papers and Reports 25(2):7385.
Huijps K, Lam TJ, Hogeveen H. 2008. Cost of mastitis: facts and perception. Journal Dairy Res 75(1):113-120.https://doi.org/10.1017/ S0022029907002932.

Lubis MP. 2016. Hubungan aplikasi celup putting (teat dipping) dengan daya produksi susu sapi perah penderita mastitis subklinis di Kunak Bogor. Bogor: Fakultas Kedokteran Hewan, IPB University.

Nurhayati IM, Martindah E. 2015.Pengendalian mastitis subklinis melalui pemberian antibiotik pada saat periode kering pada sapi perah. Wartazoa 25(2): $65-74$.

Magnusson M, Christiansson A, Svensson B. 2006. Effect of different pre-milking manual teatcleaning methods on bacterial on bacterial spore milk. Journal Dairy Science 89:38663875.https://doi.org/10.3168/jds.S00220302(06)72429-8.

Mpatswenumugabo JP et al. 2017. Prevalence of subclinical mastitis and distributions of pathogens in dairy farms of Rubavu and Nyabivu Districts Rwanda. Journal of Veterinary Medicine Article ID 8456713: 1-8. https://doi. org/10.1155/2017/8456713.

Pisestyani $\mathrm{H}$ et al. 2017. Perlakuan celup putting setelah pemerahan terhadap keberadaan bakteri patogen, Staphylococcus aureus, Streptococcus agalactiae, dan E. coli pada sapi perah penderita mastitis subklinis di peternakan KUNAK Bogor. Jurnal Sains Veteriner 35:63-70. https://doi. org/10.22146/jsv.29293.

Pranoto LH, Retnowati. 2015. Analisis Beban Kerja Sumber Daya Manusia Perusahaan. Jakarta: PPM Manajemen.

Pujiati RS, Indrianto TH. 2009. Perbedaan kandungan bakteriologis susu segar ditinjau dari pemakaian disinfektan dan tanpa disinfektan pada ambing sapi sebelum pemerahan. Jurnal Ilmu Kesehatan Masyarakat 5(1): 31-45.

Putri P Sudjatmoko, Suprayogi TH. 2015. Pengaruh lama waktu dipping dengan menggunakan larutan kaporit terhadap tampilan total bakteri dan derajat keasaman susu sapi perah. Animal Agriculture Journal 4(1):132-136.

Rahayu ID. 2007. The sensitivity of staphylococcus aureus as mastitis pathogen bacteriae into teat dipping antiseptic in dairy cows. $J$ Protein 14:31-36.

Rakhmat A, Indrawan D. 2019. Partial Budgeting of floor bedding to prevent mastitis in small 
farms in Western Java. In International Society for Economics and Social Sciences of Animal Health-South East Asia 2019 (ISESSAH-SEA 2019). Atlantis Press. https://doi.org/10.2991/ isessah-19.2019.11.

Schalm OW, Carroll EJ, Jain NC. 1971. Bovine Mastitis. Philadelphia: Lea \& Febiger.

Sanotharan N, Paghtinathan M, Nafees MSM. 2016. Prevalence of bovine subclinical mastitis and its association with bacteria and risk factors in milking cows of Batticaloa Districts in Sri Lanka. International Journal of Scientific Research and
Innovative Technology 3(6): 137-150.

Sudarnika E et al. 2019. Partial budgeting of the Application of Teat-dipping to Control Mastitis in Small Farms. Acta Veterinaria Indonesia Special Issues:24-28. https://doi.org/10.29244/ avi.0.0.24-28.

Wicaksono A et al. 2019. Role of teat dipping after milking for subclinical mastitis control and improving production of dairy cow. Buletin Peternakan 43(2):135-140. https://doi. org/10.21059/buletinpeternak.v43i2.30380. 